\title{
PKM Produk Olahan Nenas Bagi Kelompok PKK Mandiri di Kelurahan Tangkerang Barat Pekanbaru
}

\author{
ZULIA KHAIRANI ${ }^{1}$; FAIZAH KAMILAH ${ }^{2}$; EFRITA SOVIYANTI ${ }^{3}$ \\ Universitas Lancang Kuning \\ Jln. Yos Sudarso KM 08 Rumbai Telp. (0761) 52581 \\ E-mail : zuliakhairani@unilak.ac.id
}

\begin{abstract}
This community service activity is aimed at the PKK Mandiri group in the Tangkerang Barat Village, Pekanbaru. Partner problems consist of; 1 . There is a desire for entrepreneurship but do not have an idea of a product to sell, 2. There is still a lack of knowledge about how to package a good product and how to promote it. The solutions offered are: 1. Making pineapple processed products, namely pineapple diamonds from pineapple raw materials that are easily available and cheap, and 2. Increasing knowledge of marketing methods and labeling the right products so that it attracts consumer interest and effective and easy promotional efforts to small business products. The methods in this activity are: 1 . Demonstration methods / practices of making pineapple jam ready for sale 2. Presentation methods, namely explaining the correct packaging and labeling methods and the differences of each promotion method accompanied by examples through pictures and dummy products . Based on the results of the summary of the questionnaire above, there are differences in the knowledge and skills of trainees before and after this activity. Trainees already know the nutritional content and benefits of pineapple for health from the material provided by the presenter. In addition, most participants were interested in practicing re-making pineapple diamonds at home.
\end{abstract}

Keywords: Satin Products, Satin Flowers, Entrepreneurial Training, Young Women

Kelurahan Tangkerang Barat terletak di kecamatan Marpoyan Damai Kota Pekanbaru. Kelurahan ini terletak di pusat kota Pekanbaru dimana banyak terdapat pasar, mall, dan pusat-pusat kegiatan ekonomi lainnya. Keadaan ini seharusnya dapat dimanfaatkan dengan baik oleh masyarakat setempat untuk mendapatkan penghasilan dengan menjual produk yang yang sesuai keinginan konsumen. Kelompok PKK mandiri merupakan salah satu kelompok PKK di kelurahan Tangkerang Barat yang ingin berperan aktif dalam kegiatan berwirausaha. Kendala yang dihadapi yaitu belum memiliki ide jenis usaha apa yang akan dijalankan sehingga nanti produk yang dibuat bisa diterima dan laris di pasaran, mendapatkan keuntungan sehingga bisa menambah penghasilan keluarga. Kendala lainnya yaitu belum mengetahui cara-cara pengemasan, pelabelan dan upaya promosi yang efektif dan mudah dijalankan oleh UMKM.

Untuk menunjang keberhasilan usaha, salah satu hal penting yang perlu diperhatikan yaitu kemudahan dalam mendapatkan bahan baku dan harganya murah. Nenas sebagai salah satu produk pertanian local yang jumlahnya berlimpah di kota Pekanbaru dan harganya murah. Di kota pekanbaru harga nenas berkisar antara Rp 8.000-Rp 12.000 perbuah. Nenas dapat dimanfaatkan untuk diolah menjadi produk makanan sehingga nilai jualnya bisa lebih tinggi.. Pada kegiatan pengabdian kali ini kami akan mengolah nenas menjadi wajik nenas. Pilihan terhadap wajik nenas karena proses pembuatan nya mudah dan tidak memerlukan peralatan yang banyak dan layak untuk dijual.

Kreatifitas seseorang menjadi aspek penting dalam menjalankan usaha. Salah satunya yaitu memiliki kemampuan dan teknik dalam mengolah bahan baku yang mudah didapatkan dan harganya murah menjadi produk-produk yang bermanfaat dan laku di jual di pasaran. Selain itu seorang wirausaha juga harus memiliki strategi- strategi yang jitu dalam memasarkan produk yang dijualnya. 
Demikian juga hal itu juga berlaku bagi perempuan selaku ibu rumah tangga yang ingin berwirausaha dan meningkatkan kemampuannya dalam menjalankan usaha.

Gubernur Bank Indonesia (BI) Agus DW Martowardojo mengatakan bahwa BI mendorong kaum wanita mengembangkan potensi mereka dalam UMKM karena selama ini UMKM dinilai punya andil besar dan tetap hidup kala perekonomian Indonesia sedang terpuruk. Forum APEC, Women And The Economy Forum beberapa waktu yang lalu mengambil tema 'Women As Economic Drivers". Pasalnya, 96 persen pelaku kewirausahaan adalah UMKM, sementara $60 \%$ pelaku UMKM adalah perempuan. Demikian juga berdasarkan data dari kementerian koperasi dan UKM Republik Indonesia (2010) sekitar 60\% UKM dikelola oleh perempuan Indonesia. Peran perempuan di sektor UMKM umumnya terkait dengan bidang perdagangan dan industri pengolahan seperti : warung makan, toko kecil, pengolahan makanan dan industri kerajinan, karena usaha ini dapat dilakukan dirumah sehingga tidak melupakan peran perempuan sebagai ibu rumah tangga.

Demikian halnya pada sasaran program ini yaitu ibu-ibu dalam kelompok PKK Mandiri di kelurahan Tangkerang Barat yang memliki banyak waktu luang tetapi belum memiliki keterampilan yang memadai untuk berwirausaha.

Dalam kegiatan pengabdian kepada masyarakat yang akan dilakukan, diharapkan dapat menambah pengetahuan dan keterampilan ibu-ibu dalam mengolah hasil pertanian local yaitu nenas menjadi wajik nenas yang memiliki nilai jualnya lebih baik dan ibu-ibu mampu melakukan berbagai bentuk-bentuk kegiatan promosi agar produknya bisa laris di pasaran. Maka berdasarkan uraian tersebut diatas maka kami sebagai tenaga pendidik dari fakultas Ekonomi Universitas Lancang Kuning Pekanbaru mengusulkan untuk melakukan pengabdian kepada masyarakat dengan judul : "Pkm Produk Olahan Nenas Di Kelurahan Tangkerang Barat Kota Pekanbaru". Hasil identifikasi terhadap permasalahan yang dihadapi kelompok mitra sebagai calon wirausaha yang harus dipecahkan dilihat dari berbagai sudut pandang yang relevan: Banyak dari calon wirausaha masih bingung menentukan jenis produk atau jasa yang dijual karena tidak mampu untuk mengetahui kebutuhan dan keinginan konsumen

Masih kurangnya pengetahuan tentang cara pengemasan dan pelabelan produk yang baik dan disukai konsumen. Selain itu belum mengetahui berbagai macam bentuk promosi yang efektif dan mudah untuk dijalankan usaha kecil

\section{METODE}

Metode yang akan dilakukan oleh tim selama kegiatan pengabdian bagi masyarakat dengan mitra ibu-ibu PKK mandiri yaitu:

Metode Demonstrasi /Praktek. pada metode ini, tim akan mempraktekkan cara membuat wajik nenas yang siap untuk dijual. Sebelum memulai praktek, tim akan membagikan fotocopy catatan bahan baku dan cara membuat, biaya produksi dan penentuan harga jual. Tim akan mempersiapkan barang-barang dan bahanbahan yang dibutuhkan untuk praktek membuat selai nenas. Pada saat demonstrasi berlangsung, peserta dapat langsung bertanya jika ada proses yang belum dipahami. Peserta juga diperbolehkan berpartisipasi untuk membantu dalam membuat wajik nenas.

Metode Presentasi, setelah metode demonstasi selesai, akan dilanjutkan dengan presentasi tentang metode pengemasan, pelabelan, dan teknik promosi yang tepat. Presentasi dilakukan oleh tim pengabdian dengan tujuan untuk menambah pengetahuan peserta tentang bentuk-bentuk kemasan yang cocok untuk produk wajik, tulisan dan warna-warna yang cocok untuk produk makanan. Sehingga diharapkan nanti produk yang dijual dapat diterima dan laris di pasaran. Selain itu akan ditampilkan 
gambar atau dummy product dengan kemasan dan label yang siap jual. Dalam metode ini ini, juga akan diberi kesempatan bagi peserta yang ingin bertanya tentang materi yang disampaikan. Setelah kedua metode diatas dilaksankakan, maka akan disebarkan kembali kuesioner agar tim pengabdian. mengetahui pemahaman peserta terhadap kegiatan yang sudah dilakukan.

\section{HASIL}

Pada umumnya peserta mengikuti kegiatan pelatihan dengan baik dan bersemangat. Materi yang diberikan meliputi:

1. Pengetahuan tentang kandungan dan manfaat Nenas sebagai salah satu jenis buah tropis yang memiliki banyak manfaat untuk kesehatan.

2. Pengetahuan berbagai bentuk kemasan yang cocok untuk produk wajik nenas. Penyaji juga memberikan informasi harga dan tempat memesan berbagai kemasan yang dapat digunakan.

3. Pengetahuan tentang kegunaan merek, harga, dan tempat memesan label merek untuk produk makanan.

4. Cara penyajian dan pengemasan wajik nenas agar lebih menarik dan hygiene sehingga layak jual.

Berdasarkan hasil rangkuman kuesioner terdapat perbedaan pengetahuan dan keterampilan peserta pelatihan sebelum dan sesudah kegiatan ini. Peserta pelatihan sudah mengetahui kandungan gizi dan manfaat dari nenas bagi kesehatan dari materi yang di berikan penyaji. Selain itu sebagian besar peserta tertarik untuk mempraktekkan kembali membuat wajik nenas di rumah. Wajik nenas dipilih sebagai subjek pelatihan dengan mempertimbangkan bahwa produk ini pembuatannya tidak terlalu sulit baik dari sisi bahan dasarnya maupun peralatan yang diperlukan untuk pembuatannya.

\section{PEMBAHASAN}

Berdasarkan pengamatan penyaji, terlihat bahwa sebenarnya peserta pelatihan sudah memiliki keterampilan untuk membuat kue, walaupun mereka sebagian besar belum pernah membuat wajik nenas secara langsung, tapi mereka sudah dapat memperkirakan cara membuatnya, ini karena kemampuan dasar sudah mereka miliki. Akan tetapi mereka belum memiliki kemampuan teknis seperti memperkirakan berapa harga pokok untuk menghasilkan wajik nenas dari bahan pokok 1 buah nenas. Selain itu peserta juga diberitahu bagaimana cara mengemas, berapa lama waktu yang dibutuhkan untuk berproduksi, dan masa kadaluarsanya.

Di samping itu dengan kegiatan pelatihan ini kami berharap para peserta pelatihan dapat menjadikan produk wajik nenas ini sebagai salah satu produk yang dapat dijual dan menambah penghasilan. Selain bahan bakunya murah dan harga jualanya lebih terjangkau oleh masyarakat. Dengan berbagai pertimbangan diantaranya keuntungan yang diperoleh akan lebih banyak. Harapan kami para peserta pelatihan untuk kedepannya lebih baik (profesional) lagi dalam mengelola usahanya. Secara keseluruhan pelaksanaan pelatihan cukup berhasil karena peserta pelatihan mampu menguasai materi pelatihan baik dari aspek pengetahuan maupun keterampilan lebih dari $70 \%$ sesuai yang ditargetkan.

Diharapkan dengan mempunyai keterampilan membuat aneka makanan ibuibu yang tidak mempunyai pekerjaan tetap dan mempunyai keterbatasan ekonomi dapat berwirausaha secara mandiri. Disamping itu bagi ibu-ibu yang selama ini sudah mempunyai kegiatan berjualan (berwirausaha) makanan, pengetahuan dan keterampilan yang didapatkan melalui kegiatan pelatihan ini diharapkan dapat menambah wawasan serta meningkatkan motivasi untuk senantiasa mengembangkan dan mengkreasikan makanan jajanan yang dijualnya sehingga konsumen tidak bosan/ jenuh. 


\section{SIMPULAN}

Kesimpulan dari pelaksanaan kegiatan PPM ini adalah: Peserta pelatihan dapat memiliki pengetahuan tentang makanan dengan bahan, jenis dan teknik olah yang bervariasi serta mengolah wajik nenas yang menggunakan berbagai bahan dasar dengan variasi teknik olah tang praktis dan mudah. Peserta pelatihan dapat menyajikan dan mengemas makanan sehingga menjadi lebih menarik dan memiliki nilai jual yang lebih tinggi.

Berdasarkan kesimpulan diatas dapat dibuat saran sebagai berikut: Peserta dapat mengembangkan variasi produk wajik nenas melalui rasa, variasi kemasan, dan label yang lebih menarik. Peserta dapat langsung memncoba memulai usaha membuat wajik nenas karena bahan-bahannya mudah didapatkan dan alat-alat yang digunakan sederhana dan biasa diguinakan sehari-hari

\section{DAFTAR RUJUKAN}

Lodia Dwika Putri, Wardi Jeni, Khairani Zulia, 2015. Pelatihan Kewirausahaan bagi Ibu-Ibu Rumah Tangga di Kelurahan Sri Meranti Kecamatan Rumbai Kota Pekanbaru. Laporan Akhir Pengabdian Masyarakat Universitas Lancang Kuning

Nizar, Muhammad, 2014. Peranan Perempuan dalam Pengembangan Ekonomi

Islam. Diakses Melalui Jurnal.Yudharta.ac.id

Tambunan. T.H. Tulus. Dr, 2010. Globalisasi dan Perdagangan Internasional, Ghalia Indonesia, Jakarta.
2014. Kecamatan Rumbai dalam angka.

www.bpskotapekanbaru,go.id. Diakses tanggal 7 Desember 2016

- Ada Singkong Raksasa di Riau. 2016. Diakses melalui Regional. Kompas.Com 